Page $149-162$

\title{
THE IMPACT ANALYSIS OF RAW MATERIAL PRICE ON FIRM SURVIVAL
}

\author{
Sry Rahayu Febriani \\ PPIE Universitas Indonesia / Kementerian Perindustrian \\ ayu.cannavaro@gmail.com
}

\begin{abstract}
This research examines the effect of input price changes on firm survival. The increasing on import activities in the last decades indicates that manufacturing industry depends on imported raw material. It leads the industry extremely vulnerable to the global economic shocks. Some of the industries that depend on imported raw material is unlikely to survive in the crisis. Using firm level data from the Annual Survey of Manufacturers for the period 2008-2012 and probit estimation with price data of input as main variables, we find that change of input price significantly decreasing the probability of firm survival. Firm size and age as the main determinant of survival consistent with previous studies.
\end{abstract}

Keywords: Firm Survival; Imported Input Price; Local Input Price

\begin{abstract}
Abstrak
Penelitian ini berupaya menguji pengaruh perubahan harga input terhadap ketahanan perusahaan. Kegiatan impor yang terus meningkat pada beberapa dekade terakhir menunjukkan bahwa industri manufaktur tergantung kepada impor bahan baku. Hal ini mengakibatkan industri sangat rawan terhadap goncangan yang terjadi di ekonomi global. Beberapa industri yang sangat tergantung kepada bahan baku impor akan sulit bertahan ketika terjadi krisis. Dengan menggunakan data di tingkat perusahaan berdasarkan survei tahunan manufaktur dari tahun 2008 - 2012 dan estimasi probit dengan data harga input sebagai variabel utama, ditemukan bahwa perubahan harga input secara signifikan akan menurunkan probabilitas kemampuan perusahaan untuk bertahan. Ukuran perusahaan dan umur perusahaan merupakan determinan utama yang menentukan ketahanan perusahaan konsisten dengan kajian-kajian terdahulu.
\end{abstract}

Kata Kunci: Ketahanan Perusahaan; Harga Input Impor; Harga Input Lokal

Received: May 18, 2016; Revised: August 22, 2016; Approved: September 9, 2016 
The Impact Analysis of Raw Material Price on Firm Survival Sry Rahayu Febriani

\section{INTRODUCTION}

Non-oil manufacturing sector is an important sector for the implementation of the economic development. This sector is considered to be able to become the motor of the economy. However, within a period of more than a decade, this sector experienced negative growth. Data of BPS states, the contribution of manufacturing sector to GDP declined from $27.75 \%$ in 2000 to $25.55 \%$ in 2013 . It is indicates the decline of industry's role in the economy called deindustrialization. Basri (2009) mentions the decline in the number of companies in industry is one indicator of the deindustrialization.

Manufacturing companies in Indonesia is dominated by medium industries are experiencing a declining amount since 2008. Based on data, only about $74 \%$ of companies were able to survive from the period 2008 to 2012. The decline in the number of these companies will at least have an impact on employment, as most industries in Indonesia is a labor-intensive industry, that can definitely absorb more employee when developing well (Media Industry, 20I I).

As described previously, the reduction of companies might occur as a result of the firm out of business. The firm was unable to cover its cost of production with the revenue and become inefficient. According to Jovanovic (1982) those efficient firms will grow and survive and inefficient will decline and fail. One of the reasons is the high production cost due to price increases on imported raw materials. The quality and a stable supply of raw materials are the main reason why the firm decide to import. Ministry of Industry states, about $64 \%$ of the total industry in Indonesia still relies on raw materials, intermediate materials, as well as imports of capital goods to support the production process. Even some industry nearly $90 \%$ rely on imported raw materials due to the unavailability of raw materials in the country. The high imports of raw materials in the manufacturing industry indicates a highly dependence on imports. According to research conducted by Arianti (2014) found that the national industry's dependence on imported raw materials are relatively sizeable due to the elasticity of imported raw materials from domestic higher in some industrial sectors. The Ministry of industry also states there are nine industrial sectors that depend on high import, the machinery and metals, automotive, electronics, basic chemicals, food and beverages, animal feed, textiles and textile products (TPT), goods other chemicals, and pulp and paper (www.kemenperin.go.id). 
High dependence on imported raw materials is certainly not good for the independence of the national industry. National industry will be affected if there are economic shocks that occurred in the international world. Economic shocks that have occurred in 2008, which resulted in the depreciation of rupiah will certainly affect the prices of imported raw materials to be purchased by the firm to carry out production. For companies that rely heavily on imported raw materials and do not have a replacement of local raw materials will keep buying even if the cost is greater, in order to keep production running. Depreciation will result in a change in the composition of fees paid by the firm to buy imported raw materials. If the firm is not able to cover the costs with the benefits derived from export sales, in the long run, it will reduce production and profits and lead companies to close down.

The condition describes the role of price changes in the firm's decision to produce. Because the majority of the industry is still dependent on imported raw materials, the industry will be responsive to the global economic uncertainty that is absorbed through changes in raw material prices. The fluctuations in the domestic currency against the dollar in the same period withan increase in imports, leading some industry subsectors decreased the firm's performance. Figure I.I pointed that raw material prices, especially on imported raw materials can also be the cause of the failure of the firm.

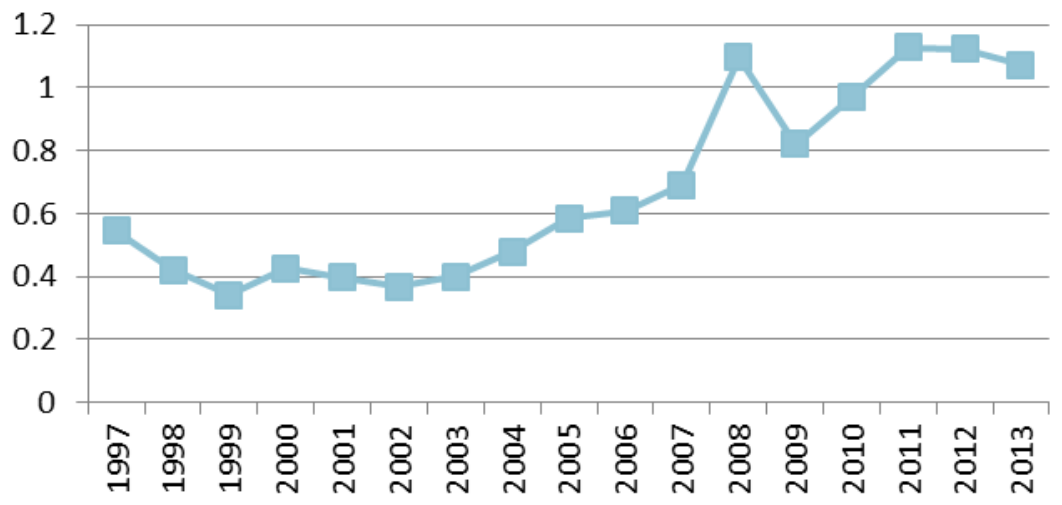

Figure I. Import Raw Material Prices (in unit value)

Source: BPS

The survival of the firm is closely related to the prospect of benefits to be obtained. Profit outlook itself is determined by the firm characteristics and industry characteristics (Jovanovic, 1982; Baggs, 2005; Soderbom et all). From an economic 
perspective, the prices of inputs and outputs is the main determinant affecting corporate profits. These factors also affect the firm's decision to continue its production or not. The previous studies on the firm survival is only focused on the influence of the firm's characteristics, i.e: size and age of the firm (Jovanovic, 1982; Baggs, 2005; Soderbom, et.al) and industry's characteristics, i.e: factor intensity and location of the firm (Bernard, 2002; Narjoko, 2006). In fact, along with the opening of the economy, the global economic uncertainty should be considered on firm's decision. Several empirical studies found that companies that import raw materials more sustainable than companies that do not use imported raw materials, it is because the imported raw materials have higher technology than local raw materials (Lopez, 2006; Wagner, 2012). However, several other studies have also shown importer would be loss if shocks to the economy such as the financial crisis happened (Narjoko, 2006; Nikitin, 2003).

Stakeholders in a firm, the shareholders are interested in the stock price, dividend profits, and workers interested in wages. Government as the regulator responsible for fulfilling this purpose. It is underlying the development of the firm that aims to end the survival of the firm itself. Thus, it is important to analyze the factors which will be the determination of a firm's ability to survive. All of them care for the long-run development of the firm and for firm survival as the ultimate goal. This paper will contribute to the industrial economic and provide evidence that it is also important to consider the input price changes as the determinant of the firm survival where the current industry situation is highly dependent on import material. To the best of my knowledges, previous studies in Indonesia has not analyzed the material prices as it can affect the survival of the firm. In fact, the price of imported raw materials can also capture the effect of the global shock that may affect the firm's decision to survive. Research by including the price of raw materials is necessary to look at the companies' behaviour in deciding whether to survive or not in the industry due to changes in raw material prices.

This paper examines how the survival probability changed as impact of raw material prices changes in the manufacturing industry. Thus, the theoretical foundation rests on the theory of firm survival, as well as how it can be influenced by changes in raw material prices. Building on the existing literature, this paper incorporates firm 
characteristics such as size, age, and ownership, as well as industry characteristics in a model of firm survival decisions.

\section{METHOD}

The empirical analysis is based on the Firm's Annual Survey of Manufacturing Industry issued by the Central Bureau of Statistics (BPS) for the year 2008 through 2012. This survey covers the Indonesian manufacturing firms with 20 or more workers. It is also includes companies from 23 sub-sectors (based on the 2-digit ISIC classification). Each firm has a unique code that characterizes the specific identity, making it easier for authors to follow the firm's existence based on PSID code. Pooled cross section is constructed as the form of the data. it means that all the data from the years 2008-2012 were collected which would be selected for the companies that survive and exit per year. As the survey is voluntary, problems that may arise is the enterprise absent from the data does not mean that the firm is really exit, but because the firm did not complete the survey. To control this problem, the author set up some alternative datasets that defines a variable $Y$ depends on the pattern of the firm's existence and choose the most excellent dataset to be used as analysis.

Import and local material Price were obtained in several stages. The first stage, dividing the value of the raw material expenditure with a physical quantity which is also called unit value. The second phase, the unit value is multiplied by the value of the raw material expenditure for each commodity. The third phase, calculating the accumulated expenditure per commodity $j$ and the value of expenditure per commodity $j$ in each firm. The fourth stage, import price variable and domestic price for each firm is then formed by dividing the accumulated expenditures per commodity $j$ with a value of expenditure per commodity. In addition to raw material prices, a variable percentage of imported material is also used as a proxy of foreign pressure on companies as well as research conducted by Bernard (2003).

Based on theoretical and empirical foundation, the author also adds some control variables that affect the survival of the firm that the input costs and output prices, the characteristics of the firm and industry characteristics. Input costsinclude wages (wage), the cost of capital (kapital). Salary (wage) is obtained from the average number of rill expenditure for production workers divided by the number of 
production workers during the observation period. The greater the wage incurred by the firm will reduce the chances of surviving firm. Cost of capital (kapital) expenditure ratio proxy for electric rill (both PLN and non PLN) of the total employees of the firm. The greater the capital costs incurred by the firm will reduce the chances of surviving firm. Output prices (P_Output), obtained in the same manner to obtain variable input prices.

Characteristics of the firm include size (Size), the age of the firm (Firm_Age), ownership of the firm (d_ownership), and export status (d_eksporter). Size is used in this study proxied by the average number of workers / employees owned by a firm (production and non-production) per day of well-paid workers and are not paid during the year of observation. The greater the amount of labor that is owned by the firm reflect the size of the firm increases. Firm_Age used in this study was calculated from the length of time the firm from the initial start of production until the year 2008. Started operation year obtained from the survey data IBS in 2006. The firm which not in the survey IBS 2006 is newly established in 2008. Age is expressed in terms of years. Variable ownership of the firm (d_ownership) is a dummi, indicator $I$ is given to the companies owned by foreigners and 0 for others. The firm's ownership is obtained by looking at the percentage of capital on the questionnaire. Ownership is divided into two groups: foreign and domestic (the central government, local government and national private sector), and then compared the percentage of each group. It is categorized as foreign if the percentage of foreign capital greater than domestic capital. Export status (d_eksporter) is a dummy variable, given indicator $I$ if the firm is oriented on export sales and 0 for others.

Characteristics of the industry consists of the firm's locations and intensity factor. Firm's location (d_awa_Bali) is a dummy variable, given indicator $I$ to the companies located in Java and Bali, and 0 for the other. This variable is formed by identifying the location of the firm by province. Intensity factor grouped by 2-digit ISIC Rev.3 and divided into three groups, namely: Labor Intensive, Intensive Resources, and Capital Intensive. The division of this category is based on research conducted by Narjoko \& Hill (2006) and compared with UNIDO Report 20I3. Industry categorized as Labor Intensive industry has a code of ISIC I5, 16, 17, 18, 19, 20, 21, 22,36 and 37. Industry categorized as Intensive Resources industry has a code of ISIC 23, 25, 26, 27 
and 28. industry categorized as Intensive Capital industry has a code of ISIC 24, 29. 30, $31,32,33,34$, and 35.

The model used to measure the firm's ability to survive using probit analysis, following probit model proposed by Baggs (2005). Accordingly, the equation can be written as:

$\operatorname{Pr}\left(\right.$ Survive $\left._{i}\right)=\alpha+\beta_{1}$ PImp $_{i}+\beta_{2}$ PLok $_{i}+\beta_{3} \operatorname{lnWage}_{i}+\beta_{4} \operatorname{lnRent}_{i}+\beta_{5}{\ln P O u t p u t_{i}}$ $+\beta_{6}$ Size $_{i}+\beta_{7}$ Firm_Age $e_{i}+\beta_{8}$ AgeSq $_{i}+\beta_{9}$ Sharelmp $p_{i}$

$$
+\delta \_E k s p o r t e r_{i}+\delta \_D u m_{-} O w n_{i}+\delta \_D u m \_J a w a B a l i_{i}
$$

$+\delta \_$Resources_Intensive $e_{i}+\delta \_$Capital_Intensive $e_{i}+\varepsilon_{i}$

Table I. Descriptive Statistics

\begin{tabular}{llrrrrr}
\hline Variabel & & Min & \multicolumn{1}{c}{ Max } & Mean & Std. Dev & Obs. \\
\hline Harga Input & (p_Imp) & 0 & $29,100,000$ & 3,495 & 227,363 & 24536 \\
& (P_Lok) & 0 & $17,000,000$ & 6,003 & 165,959 & 24536 \\
Upah & (Wage) & 44.14 & 884,428 & 9,365 & 11,653 & 24532 \\
BiayaKapital & (Kapital) & 0 & $1,477,152$ & 3,719 & 20,080 & 24536 \\
Harga Output & (P_Output) & 0 & $224,000,000$ & 68,529 & $2,500,644$ & 23910 \\
Kepemilikan & (d_Ownership) & 0 & $\mathrm{I}$ & 0.0724 & 0.259127 & 24536 \\
Ukuran Perusahaan & (SizeAv) & 20 & 37,193 & 174.7046 & 640.0104 & 24536 \\
Usia Perusahaan & (Firm_Age) & 0 & 108 & 15.1349 & 12.2116 & 24536 \\
Status Ekspor & (d_Eksportir) & 0 & $\mathrm{I}$ & 0.2239 & 0.4169 & 24536 \\
Lokasi & (d_Jawa Bali) & 0 & $\mathrm{I}$ & 0.8385 & 0.3680 & 24536 \\
Share Input Imp & (SharelmpAv) & 0 & $\mathrm{I}$ & 0.0815 & 0.2184 & 24536 \\
Dummy & (d_Resources) & 0 & $\mathrm{I}$ & 0.1887 & 0.3913 & 24536 \\
FaktorIntensitas & (d_Capital) & 0 & $\mathrm{I}$ & 0.1036 & 0.3048 & 24536 \\
& (d_Unskill) & 0 & $\mathrm{I}$ & 0.7076 & 0.4549 & 24536 \\
\hline
\end{tabular}

\section{RESULT AND DISCUSSION}

We started by looking at some descriptive statistics concerning two groups of firms, those that survive and those do not. When we look on aggregate at those firms that existed in 2008 and are still alive at the end of 2012, some interesting points arise. On Average, the import price on survivor less than exit. That is, the survivor firm have relatively lower import prices than companies that go out. This provides an early indication that the average price of imported raw materials is high to the exit firm. 
The Impact Analysis of Raw Material Price on Firm Survival Sry Rahayu Febriani

Table 2. Descriptive Statistics Survival and Exit Firms

\begin{tabular}{|c|c|c|c|}
\hline All Firms & & Survivor & Exit \\
\hline Observation & 24,536 & 19,469 & 5,067 \\
\hline \multirow[t]{2}{*}{ p_Imp } & 3,495 & 2,834 & 6,035 \\
\hline & $(227,363)$ & $(146,633)$ & $(374,024)$ \\
\hline \multirow[t]{2}{*}{ P_Lok } & 6,003 & 6,523 & 4,007 \\
\hline & $(165,959)$ & $(176,206)$ & $(127,888)$ \\
\hline \multirow[t]{2}{*}{ Wage } & 9,365 & 10,156 & 6,322 \\
\hline & $(11,653.02)$ & $(12,570)$ & $(6,224)$ \\
\hline Kapital & $\begin{array}{l}169,268 \\
(3,821,618)\end{array}$ & $\begin{array}{l}3,922 \\
(21,032)\end{array}$ & $\begin{array}{l}2,942 \\
(15,877)\end{array}$ \\
\hline \multirow[t]{2}{*}{ P_Output } & 68,529 & 79,842 & 23,004 \\
\hline & $(2,500,644)$ & $(2,738,385)$ & $(I, I|3,07|)$ \\
\hline \multirow[t]{2}{*}{ SizeAv } & 174.7046 & 200.09 & 77.16 \\
\hline & $(640.01)$ & ( 706.73) & (228.88) \\
\hline \multirow[t]{2}{*}{ Firm_Age } & 0.0724 & 15.7506 & $12.769 \mid$ \\
\hline & $(0.2591)$ & (12.37) & $(11.28)$ \\
\hline \multirow[t]{2}{*}{ d_Eksportir } & 0.2239 & 0.2414 & 0.1567 \\
\hline & $(0.4169)$ & $(0.4279)$ & $(0.3636)$ \\
\hline \multirow[t]{2}{*}{ SharelmpAv } & 0.08 & 0.09 & 0.05 \\
\hline & $(0.2184)$ & $(0.2269)$ & $(0.1788)$ \\
\hline \multirow[t]{2}{*}{ d_Ownership } & 0.0724 & 0.0824 & 0.0337 \\
\hline & $(0.259 I)$ & $(0.2750)$ & $(0.1806)$ \\
\hline \multirow[t]{2}{*}{ d_Jawa Bali } & 0.8385 & 0.8512 & 0.7896 \\
\hline & $(0.3680)$ & $(0.3559)$ & $(0.4076)$ \\
\hline \multirow[t]{2}{*}{ d_Resources } & 0.1887 & 0.2045 & 0.1281 \\
\hline & $(0.39 \mid 3)$ & $(0.4034)$ & $(0.3342)$ \\
\hline \multirow[t]{2}{*}{ d_Capital } & 0.1036 & 0.1161 & 0.0559 \\
\hline & $(0.3048)$ & $(0.3203)$ & $(0.2297)$ \\
\hline \multirow[t]{2}{*}{ d_Unskill } & 0.7076 & 0.6794 & 0.8161 \\
\hline & $(0.4549)$ & $(0.4667)$ & $(0.3875)$ \\
\hline
\end{tabular}

Source : Author's computation

Based on the characteristics, the survivor has greater average on age and size than that did not survive. These results are consistent with the theory where firm's ability to survive will increase in accordance with increasing age of the firm. In terms of ownership, companies in the manufacturing sector which is owned by domestic still more than those owned by foreigners, which is about $91.76 \%$. Only about $8,24 \%$ owned by a foreign firm. However, when viewed from the proportion of foreign companies to survive more than a firm owned by a local.

Similarly, company engaged in the export and survive on average larger than companies that do export and did not survive. The average company oriented on export sales was about 22 percent. It is clear that companies in Indonesia most still rely on sales in the domestic market. The data can also be seen that among the companies that do export, survivor have a greater portion than exit. 
When viewed from the location, about $83.85 \%$ firm located in Java and Bali Island. This location are chosen because the ease of transport and access to input factors. Java and Bali have better infrastructure than other islands and also it is easier to access labor in the island because the population is more than the other islands in Indonesia. On average, among firm located in Java and Bali, survivor is larger than exit.

In terms of the intensity factor seen that manufacturing companies are still dominated by unskilled intensive. Industries that rely on unskilled labor (unskilled intensive) dominates Indonesian manufacturing which is around 7I percent, whereas the industries that rely on natural resources (resources Intensive) is about $18 \%$.

Table 3 show the estimation result of the empirical specifications are used to answer research questions posed. The estimation result shown is the best estimate result of the two data sets which are designed based on the definition of dependent variables as described in the previous section. In addition, the author will also test the model into two spesification, ie estimation using only the characteristics of companies (column I) and the second specification also incorporate industry characteristics variables (column 2).

The estimation results showed in both specifications, there is no change in direction of the price of imported raw materials and statistically significant negative effect on the possibility of the firm to survive. This indicates that the possibility of companies to survive or not depends on the price of imported raw materials. These results are closely related to the influence of the global economic environment. Global economic shocks that occur, providing choice to the firm that has been importing raw materials for the purchase of raw materials from within the country. However, the results showed, the firm can not obtain the same raw materials from local raw materials, so companies have to keep buying imports that have higher prices due to economic shocks. Domestic raw material prices also showed a negative direction, but not statistically significant in demonstrating the possibilities for companies to survive in the industry or not. These findings also indicate that the manufacturing industry is still dependent on raw materials derived from imports, so that the price changes on domestic raw material did not have a significant influence on the likelihood of the firm to survive or not. This implies that an increase or decrease in the price of local raw materials, has no effect on the firm's ability to survive or exit the industry. 
The Impact Analysis of Raw Material Price on Firm Survival Sry Rahayu Febriani

Interpretation of the results of the marginal effect predicted that the rise in raw material prices will reduce the survival of the firm amounted to I.3 percent.

Table 3.ProbitEstimation Result

\begin{tabular}{|c|c|c|c|c|}
\hline & (I) & & (2) & \\
\hline \multirow{2}{*}{ p_Imp } & -0.081 & $* * *$ & -0.077 & $* * *$ \\
\hline & 0.029 & & 0.027 & \\
\hline \multirow[t]{2}{*}{ P_Lok } & -0.041 & & -0.049 & \\
\hline & 0.055 & & 0.054 & \\
\hline \multirow[t]{2}{*}{ Wage } & $0.57 \mid$ & $* * *$ & 0.573 & $* * *$ \\
\hline & 0.018 & & 0.018 & \\
\hline \multirow[t]{2}{*}{ Kapital } & -0.008 & $* *$ & -0.013 & $* * *$ \\
\hline & 0.004 & & 0.004 & \\
\hline \multirow[t]{2}{*}{ P_Output } & 0.032 & $* * *$ & 0.037 & $* * *$ \\
\hline & 0.004 & & 0.004 & \\
\hline \multirow[t]{2}{*}{ SizeAv } & 0.000 & $* * *$ & 0.000 & $* * *$ \\
\hline & 0.000 & & 0.000 & \\
\hline \multirow[t]{2}{*}{ Firm_Age } & 0.023 & $* * *$ & 0.022 & $* * *$ \\
\hline & 0.002 & & 0.002 & \\
\hline \multirow{2}{*}{ Age2 } & 0.000 & $* * *$ & 0.000 & $* * *$ \\
\hline & 0.000 & & 0.000 & \\
\hline \multirow[t]{2}{*}{ d_Eksportir } & 0.074 & $* * *$ & 0.103 & $* * *$ \\
\hline & 0.027 & & 0.027 & \\
\hline \multirow[t]{2}{*}{ SharelmpAv } & -0.100 & $*$ & -0.142 & $* *$ \\
\hline & 0.056 & & 0.058 & \\
\hline \multirow[t]{2}{*}{ d_Ownership } & 0.056 & & 0.064 & \\
\hline & 0.050 & & 0.051 & \\
\hline \multirow[t]{2}{*}{ d_Jawa Bali } & & & 0.332 & $* * *$ \\
\hline & & & 0.026 & \\
\hline \multirow[t]{2}{*}{ d_Resources } & & & 0.282 & $* * *$ \\
\hline & & & 0.027 & \\
\hline \multirow[t]{2}{*}{ d_Capital } & & & 0.044 & \\
\hline & & & 0.040 & \\
\hline Log Likelihood & -11152.7 & & -11014.4 & \\
\hline Observations & 24532 & & 24532 & \\
\hline Correctly Classified & $80.78 \%$ & & $80.83 \%$ & \\
\hline Pseudo R2 & 0.1072 & & 0.1182 & \\
\hline
\end{tabular}

Source : Author's computation

The share of imported raw materials become essential analyzed due to the pressures of globalization on the firm can also be seen in this variable. From the results above, the proportion of imported raw materials prove significantly, the greater will minimize the possibility of the firm to survive. These results also confirm the influence of the raw materials' price that can negatively affect the firm's ability to survive. In 
addition, the research also found that companies with the share of imported raw materials tend to sell products at a higher price. These results are consistent with the theory of "pricing to firm" which says that markups depending on the technology and the competitive environment of the buyer (Koren, 2007).

The results also showed that wages provide a positive direction and significant in the firm's ability to survive. It is not in accordance with the theory of profit maximization companies that claim given the higher wage will reduce corporate profits. But some studies have also mentioned that wages are not only considered as an expense of the firm, but it can also be regarded as an indicator of human qualities. The higher the wage provided that it shows the higher quality level of labor. Companies that hire more human capital will be better able to adapt to technological changes that occurred (Gort, 2002). For this reason, its naturally when wages increasing the survival of the firm. Cost of capital is proxied by the value of the average electricity firm issued decreases the chances of the firm to survive. The price of the firm's products have a positive influence on the survival of the firm. These results are consistent with the theory of the firm to maximize profits, where the rise in output prices will boost the firm's profits.

Other results found that export variables showed a positive direction towards the survival of the firm. That is, the firm oriented on export sales have a greater probability of survival compared to companies that do not export. These results indicate that in the period of the study, the export-oriented companies have benefited from the weakening domestic currency. In addition, in this period where commodity boom occurred, Indonesia is still be the largest producer of export commodities. Thus, the firm's ability to survive natural to be higher in companies that do export than others.

The estimation results in Table 2 also shows, for both models estimation, age of the firm and size of the firm significantly positive effect on the survival of the firm. Consistent with previous studies (Jovanovic, 1982; Baggs, 2005), firm age and size of the firm has a positive and significant effect on the survival of the firm. It supports the economic theory of "Economic of Scale" and "Learning Curve". The larger the scale of the firm as measured by the amount of labor, making workers can specialize their activities, so it would be more productive. Increased costs still smaller than the output 
produced. Similarly to the age of the firm, the firm will absorb more appropriate to the age of technology companies. The longer the firm operates, the firm's employees will be more experienced and more effective in the use of firm resources.

The addition of industry characteristics as control variables does not alter the effect of main variables analyzed. Consistent with previous studies, consentrated location, in this study using the Java-Bali region, giving a positive and significant impact on the survival of the firm. Firms located in the Java-Bali has a greater probability of survival compared with firms that are not located in the Java-Bali. It proves that the location with better infrastructure and closer to the source of input has a positive effect on the survival of the firm.

The estimation results further demonstrate the ability to survive connected to the intensity of the firm. Resource intensive industry had a significant probability of survival greater than companies that are unskilled intensive. This implies that the manufacturing industry which process natural resources still have a comparative advantage in the domestic as well as international. Due to the weakening of the exchange rate at the time of crisis, the manufacturing industry to process natural resources take advantage of this momentum to increase export sales especially demand for these products is still high. In accordance with the findings of Forbes (2002), the crisis will benefit the firm sales-oriented commodities. These results also confirm previous results showing that companies that make an export has the ability to withstand higher than others. From these findings could also explain, that in this period, more favorable for Indonesia's manufacturing industry to sell commodities on the international market than selling the products produced by labor-intensive industries such as textiles and apparel products.

\section{CONCLUSION}

The findings suggest imported input prices were found significantly affect the firm's ability to survive.Decrease the possibility of the firm to survive due to price increases on imported raw materials explained that the use of imported raw materials is still a problem in the manufacturing industry. Another result to note that the proportion of raw material imports to total raw material has a significant influence on the firm's ability to survive and leave a negative direction. By implication, the higher 
used of imported raw material the smaller probability to survive. Companies owned by foreigners in this study did not prove to be significant in affecting the possibility of the firm to survive. That is, there is no difference in the behavior of companies owned by foreign companies or domestic to the ability to survive in the industry.

The results of subsequent studies showed that the export-oriented companies have a greater probability of survival. This finding is also consistent with the results that the firm based on the processing of natural resources have a greater ability to survive. In the era of the 2000 s, Indonesia is one of the largest commodity-producing countries in the world, so it is natural if the export of natural resources that can increase the likelihood of this great firm to survive. The policy implications of this result are: First, governments are encouraged to support capacity building for upstream and intermediate industry. Secondly, resources endowment is owned by Indonesia which is normally located at the upstream industry, can be a driving force for the downstream industry. Providing incentives to firms in upstream and also having downstream policy-based Natural Resources is appropriate to increase the value added of manufacturing industry in Indonesia.

\section{REFERENCES}

Alvarez, R. (2009). Multinationals and Plant Exit: Evidence from Chile. International Review of Economics and Finance.Vol.18, pp. 45-5I.

Arianti, R. K. (20I4). Ketergantungan Beberapa Sektor Industri Terhadap Bahan Baku Impor. Buletin Ilmiah Litbang Perdagangan.

Baggs, J. (2005). Firm Survival And Exit In Response To Trade. Canadian Journal of Economics Vol. 38, No. 4, pp. I364-I383.

Baggs, J. (2009). Firm Survival, Performance, and the Exchange Rate. The Canadian Journal of Economics, Vol. 42, No.2, Pp. 393-42I.

Bernard, A. B. (2002). The Deaths of Manufacturing Plants. NBER Working Paper No.9026.

Bernard, A. B. (2003). Foreign Owners and Plant Survival. NBER Working Paper No. 10039.

Bernard, A. B. (2007). Firm Structure, Multinationals, and Manufacturing Plant Death. The Review of Economics and Statistics Vol.LXXXIX. 
The Impact Analysis of Raw Material Price on Firm Survival Sry Rahayu Febriani

Cameron, A.C. (2009). Microeconometrics using STATA. Texas: Stata Corp LP.

Conway, P. (2005). Import Price Pressure on Firm Profitability and Input Choice: The Case of Textiles. Retrieved from http://www.researchgate.net/publication/22838I697.

Forbes, K. J. (2002). Cheap Labor Meets Costly Capital : The Impact of Devaluation on Commodity Firms. Journal of Development Economics.Vol. 69, pp. 335-365.

Gorg, H. (2003). Footloose Multinationals. The Manchestes School.Vol 7I No.I, pp. I19.

Jovanovic, B. (1982). Selection and The Evolution of Industry. Econometrica,Vol.50 No.3, pp. 649-670.

Lopez, R. A. (2006). Imports of intermediate inputs and plant survival. Economics Letters, Vol. 92 (I), pp. 58-62.

Michael Gort, J. B.-H. (2002). The Survival of Industrial Plants. Center for Economic Studies, U.S. Bureau of the Census Working Paper.

Naminia, J. E. (2013). Export growth and firm survival. Economics Letters.Vol. 99, pp. $48 \mathrm{I}-486$.

Pindyck, R. S. (2009). Microeconomics. New Jersey: Pearson.

Soderborn, M. (2006). The Determinants of Survival among African Manufacturing Firms. Economic Development and Cultural Change.Vol.54 (3), pp. 533-555.

Wagner, J. (20/3). Exports, imports and firm survival: first evidence for manufacturing enterprises in Germany. Rev World Econ.Vol. I49, pp. II3-130.

Wooldridge, J. M. (2002). Econometrics Analysis of Cross Section and Panel Data. Massachusetts: The MIT Press. 